\title{
HUBUNGAN JENIS, LAMA PEMAKAIAN DAN HARGA DIRI DENGAN RESILIENSI PENGGUNA NAPZA FASE REHABILITASI
}

\author{
RELATIONSHIP OF TYPES, OLD USE AND SELF ESTEEM WITH \\ RESILIENCE OF REHABILITATION PHASE USERS
}

\author{
Mohd Syukri \\ Jurusan Keperawatan Poltekkes Kemenkes Jambi \\ Kontak Penulis: syukrimohd15@gmail.com
}

\begin{abstract}
ABSTRAK
Fenomena penyalahgunaan narkotika, psikotropika, dan zat adiktif lain (Napza) di kalangan generasi muda semakin mencemaskan karena telah menjangkau hampir seluruh lapisan masyarakat. Tujuan penelitian ini adalah untuk mengetahui hubungan jenis napza, lama pemakaian dan harga diri dengan resiliensi pengguna pada fase rehabilitasi. Penelitian ini telah dilaksanakan di RSJD Provinsi Jambi, BNN Kota Jambi, dan yayasan Natura Kota Jambi dengan melibatkan responden sebanyak 65 orang melalui teknik total sampling. Hasil penelitian menunjukkan sebagian besar pengguna napza adalah pemakai lama, harga diri rendah dimiliki oleh sebagian besar responden, dan responden yang memiliki resiliensi sedang adalah terbanyak. Penemuan yang lain menunjukkan adanya hubungan bermakna antara lama pemakaian dengan resiliensi pengguna, adanya hubungan bermakna antara jenis napza dengan resiliensi pengguna, dengan adanya hubungan bermakna antara harga diri dengan resiliensi pengguna. Hasil temuan ini layaknya dapat digunakan sebagai salah satu bahan acuan dalam pemberantasan penyalahgunaan napza yang sering terjadi dimasyarakat melalui penyuluhan-penyuluhan, ataupun tindakan-tindakan yang diperlukan oleh pihak yang terkait.
\end{abstract}

Kata kunci: napza; lama pemakaian; harga diri; resiliensi; rehabilitasi

\begin{abstract}
The phenomenon of abuse of narcotics, psychotropic and other addictive substances (drugs) among the younger generation is increasingly worrying because it has reached almost all levels of society. The purpose of this study was to determine the relationship between drug types, duration of use and self-esteem with user resilience in the rehabilitation phase. This research has been carried out in RSJD Jambi Province, Jambi City National Narcotics Agency, and Jambi City Natura Foundation involving 65 respondents through total sampling technique. The results showed that the majority of drug users were long-time users, the low self-esteem was owned by most respondents, and the respondents who had moderate resilience were the most. Another finding showed a significant relationship between the duration of use and user resilience, there was a significant relationship between types of drugs and user resilience, with a meaningful relationship between self-esteem and user resilience. These findings can be used as a reference in combating drug abuse that often occurs in the community through counseling or actions needed by the parties concerned.
\end{abstract}

Keywords: Napza; long usage; self-esteem; resilience; rehabilitation 


\section{PENDAHULUAN}

Permasalahan penyalahgunaan napza saat ini menjadi momok yang menakutkan karena telah sampai pada tingkat anak-anak Sekolah D asar. Secara universal penyalahgunaan napza dapat mengancam dan merusak masa depan penggunanya, bahkan dapat menimbulkan kejahatankejahatan lainnya akibat dari ketergantungan terhadap napza tersebut. Narkotika, Psikotropika, dan Zat Adiktif (NAPZA) adalah bahan/zat/obat yang bila masuk ke dalam tubuh manusia akan mempengaruhi tubuh terutama otak/susunan saraf pusat, sehingga menyebabkan gangguan kesehatan fisik, psikis, dan fungsi sosialnya karena terjadi kebiasaan, ketagihan (adiksi) serta ketergantungan.

Berdasarkan World Drug Report dari United Nations Office on Drugs and Crime (UNODC), sekitar 200 juta orang di seluruh dunia menggunakan napza jenis narkotika dan psikotropika secara ilegal. Kanabis merupakan jenis napza yang paling sering di gunakan, diikuti dengan amfetamin, kokain, dan opioida (Natsir, 2012). Syarif \& Tafa, (2008) mengatakan di berbagai negara sekitar $50 \%$ pengguna narkoba suntik (penasun) hidup dengan HIV/AIDS, bahkan di beberapa wilayah di dunia, sekitar 90\% pemakai narkotik dengan jarum hidup dengan HIV/AIDS. Lebih dari 95\% penasun terdapat di negara berkembang. Kemungkinan lebih dari sepuluh juta paling sedikit, satu juta Pengguna Narkoba Suntik (Injegting Drug User/IDU) diseluruh dunia menderita HIV atau AIDS.

Berdasarkan laporan akhir survei nasional perkembangan penyalahgunaan narkoba tahun anggaran 2014, jumlah penyalahguna narkoba diperkirakan ada sebanyak 3,8 juta sampai 4,1 juta orang yang pernah memakai narkoba dalam setahun terakhir (current users) pada kelompok usia 10-59 tahun. Jadi, ada sekitar 1 dari 44 sampai 48 orang berusia 10-59 tahun masih atau pernah memakai narkoba pada tahun 2014. Angka tersebut terus meningkat dengan merujuk hasil penelitian yang dilakukan Badan Narkotika Nasional (BNN) dengan Puslitkes UI dan diperkirakan jumlah pengguna narkoba mencapai 5,8 juta jiwa pada tahun 2015 (Phadli, 2015). Sedangkan untuk kasus pengguna narkoba suntik (penasun) sampai saat ini di Indonesia di perkirakan terdapat 500 ribu sampai dengan 1,3 juta pengguna narkoba suntik (Injecting Drug User-IDU) (Galatea, 2007).

Jumlah pengguna napza pada tahun 2015 di Provinsi Jambi sebanyak 681 orang, tahun 2016 sebanyak 466 orang, dan 2017 sebanyak 684 orang. Badan Narkotika Nasional Kota Jambi menyebutkan pengguna yang ada di kota Jambi yang menjalani rehabilitasi pada 2015 sebanyak 30 orang yang mengikuti program rawat inap dan 27 orang rawat jalan, pada tahun 2016 sebanyak 33 orang yang mengikuti program rawat inap dan 26 orang yang rawat jalan, dan tahun 2017 sebanyak 42 orang yang mengikuti program rawat inap dan 7 orang rawat jalan (Badan Narkotika Nasional, 2017).

Sebagian besar pengguna mengalami relapse (kembali menggunakan Napza) karena kembali bergaul dengan lingkungan sesama pecandu. Seseorang individu yang berada dalam lingkungan yang beresiko (lingkungan pergaulan napza) akan mengalami rentan terpengaruh untuk menggunakan napza kembali. Untuk mempertahankan kepulihan klien rehabilitasi, maka di butuhkan adanya resiliensi. Resiliensi merupakan faktor yang berperan penting untuk dapat bertahan mengatasi masalah dan mempertahankan kesehatan dalam menghadapi lingkungan yang beresiko (Setyowati, 2010). Resiliensi sebagai karakteristik personal yang dapat meringankan dampak negatif dan mendorong adaptasi positif terhadap stres yang di hadapi. Dalam mencapai proses resiliensi dipengaruhi oleh faktor internal dan eksternal. Faktor internal meliputi harga diri, spiritual, sedangkan faktor eksternal meliputi dukungan keluarga, teman sebaya, masyarakat (Snyder \& Lopez, 2007). Menurut Rosida, dkk (2015), faktor internal dalam penyalahgunaan Napza diantaranya, mudah terpengaruh, ingin mencoba hal baru, mengikuti tren, tidak percaya 
diri/harga diri yang rendah. Sementara faktor eksternalnya yaitu lingkungan yang menekan, keluarga yang tidak utuh, keluarga yang kurang memperhatikan, memiliki keluarga yang menggunakan narkoba, serta berteman dekat dengan sesama pengguna.

Suatu penelitian yang telah dilakukan oleh Mustira, D (2017) tentang hubungan jenis napza dan lama pemakaian dengan resiliensi pengguna menunjukkan hubungan yang signifikan, dimana jenis napza narkotika dengan pemakaian yang sudah lama (lebih dari setahun) akan memperlihatkan resiliensi yang rendah pada individu. Selain jenis Napza dan lama pemakaiannya, harga diri (self esteem) juga menjadi salah satu faktor yang berpengaruh terhadap resiliensai pengguna napza. Hidayati (2014) menyebutkan pentingnya seseorang memiliki self esteem atau harga diri, hal ini dibuktikan dari hasil penelitian dimana semakin tinggi nilai self esteem maka semakin tinggi resiliensi seseorang, sebaliknya semakin rendah nilai self esteem maka semakin rendah pula resiliensinya. Akan tetapi, sebagian besar pengguna narkoba memiliki perasaan bersalah, tidak berguna, dan mudah tersinggung sehingga mengakibatkan pengguna tidak memiliki kesejahteraan sosioemosional, perasaan-perasaan tersebut pun masih sering muncul pada pengguna narkoba, hal itu yang kadang membuat pengguna narkoba memiliki keinginan untuk kembali menggunakan narkoba.

Penelitian ini dinilai penting dalam mengetahui sejauh mana resiliensi dari para pengguna napza yang dalam tahapan rehabilitasi. Sehingga dapat dikaitkan dengan jenis, lama pemakaian, dam harga diri yang dapat memacu seseorang untuk memiliki self esteem yang cukup untuk kembali berbaur dengan masyarakat dan tidak kembali terjerumus kepada napza.

\section{METODE PENELITIAN}

Penelitian ini adalah penelitian kuantitatif menggunakan pendekatan potong silang (Cross Sectional). Teknik pengambilan sampel secara total sampling. Penelitian dilakukan untuk menganalisa hubungan jenis, lama pemakaian, harga diri dengan resiliensi pengguna napza. Sampel berjumlah 65 orang. Instrumen yang digunakan untuk mengukur resiliensi mengadopsi pada instrumen resiliensi Setyowati, dkk (2010). Data dianalisis secara univariat dan bivariat dengan uji chi-square.

\section{HASIL PENELITIAN}

1. Analisis Univariat a. Jenis Napza

Tabel 1. Distribusi Responden berdasarkan Jenis Napza yang dipakai

\begin{tabular}{cccc}
\hline No & Jenis Narkoba & Jlh & Persentase (\%) \\
\hline 1 & Narkotika & 23 & $35,3 \%$ \\
\hline 2 & Psikotropika & 8 & $12,3 \%$ \\
\hline 3 & $\begin{array}{c}\text { Narkotika }+ \\
\text { Psikotropika }\end{array}$ & 34 & $52,3 \%$ \\
\hline & Jumlah & 65 & $100 \%$ \\
\hline
\end{tabular}

Hasil penelitian yang diperoleh dari 65 responden jenis napza narkotika dan psiotropika (kombinasi) paling banyak dipakai yaitu sebesar (52,3\%). Sedangkan pengguna psikotropika paling sedikit ditemukan, yaitu sebanyak 8 responden (12,37\%). Narkotika jenis heroin paling banyak digunakan (40\%), ganja (32,3\%) dan morfin (9,2\%). Psikotropika jenis sabu paling banyak digunakan oleh responden. 
b. Lama Pemakaian

Tabel 2. Distribusi Responden Berdasarkan Lama Pemakaian Napza

\begin{tabular}{ccc}
\hline Lama Pemakaian & Jlh & $\%$ \\
\hline$<6$ bulan & 17 & 26,2 \\
\hline$>6$ bulan & 48 & 73,8 \\
\hline
\end{tabular}

Diketahui paling banyak responden telah menggunakan napza $73,8 \%$ sudah lama (lebih dari 6 bulan).

c. Harga diri

Tabel 3. Distribusi Responden berdasarkan harga diri

\begin{tabular}{ccc}
\hline Harga diri & Jlh & $\%$ \\
\hline Tinggi & 7 & 10,7 \\
\hline Rendah & 58 & 89,3 \\
\hline
\end{tabular}

Diketahui paling banyak responden pengguna napza memiliki harga diri rendah yaitu $89,3 \%$.

c. Resiliensi

Tabel 4. Distribusi Responden Berdasarkan Resiliensi

\begin{tabular}{ccc}
\hline Resiliensi & Jlh & $\%$ \\
\hline Tinggi & 18 & 27,7 \\
\hline Sedang & 24 & 36,9 \\
\hline Rendah & 23 & 35,4 \\
\hline
\end{tabular}

Diketahui sebagian besar responden memiliki resiliensi tingkat sedang yaitu 36,9\%.

2. Analisis Bivariat

a. Hubungan jenis napza dengan resiliensi

Tabel 5. Hubungan Jenis Napza dengan Resiliensi

\begin{tabular}{lccccc}
\hline \multirow{2}{*}{ Jenis Napza } & \multicolumn{3}{c}{ Resiliensi } & \multirow{2}{*}{ OR } & $P$ \\
\cline { 2 - 4 } & Tinggi & Sedang & Rendah & 95\% & Value \\
\hline Narkotika & 15 & 19 & 31 & & \\
\hline Psikotropika & 16 & 23 & 26 & & \\
\cline { 1 - 4 } $\begin{array}{l}\text { Narkotika }+ \\
\text { psikotropika }\end{array}$ & 18 & 20 & 27 & 0,007 & 0,007 \\
\hline
\end{tabular}

Berdasarkan hasil penelitian, diketahui pengguna napza jenis narkotika paling banyak memiliki resiliensi yang rendah (47,7\%). Hasil uji statistik memperlihatkan nilai $p$-value $=$ $0,007(\mathrm{p}<0,05)$ yang berarti bahwa ada hubungan bermakna antara jenis napza dengan resiliensi pengguna napza. Pada tabel diatas, pengguna napza lebih dari 1 jenis (narkotika+psikotropika) belum bisa diketahui secara pasti mana yang lebih dominan mempengaruhi resiliensi.

b. Hubungan lama pemakaian napza dengan resiliensi

Tabel 6. Hubungan lama pemakaian napza dengan resiliensi

\begin{tabular}{|c|c|c|c|c|c|}
\hline \multirow{2}{*}{$\begin{array}{l}\text { Lama pemakaian } \\
\text { Napza }\end{array}$} & \multicolumn{3}{|c|}{ Resiliensi } & \multirow[t]{2}{*}{ OR 95\% } & \multirow[t]{2}{*}{$P$ Value } \\
\hline & Tinggi & Sedang & Rendah & & \\
\hline Baru & 38 & 12 & 15 & \multirow{2}{*}{4,667} & \multirow{2}{*}{0,034} \\
\hline Lama & 16 & 22 & 27 & & \\
\hline
\end{tabular}


Berdasarkan hasil penelitian, diketahui penggunaan napza yang telah lama paling banyak memiliki resiliensi yang rendah $(41,5 \%)$. Hasil uji statistik memperlihatkan nilai $p$ value $=0,034(\mathrm{p}<0,05)$ yang berarti bahwa ada hubungan bermakna antara lama pemakaian napza dengan resiliensi pengguna napza.

c. Hubungan harga diri dengan resiliensi

Tabel 7. Hubungan Harga Diri dengan Resiliensi

\begin{tabular}{lccccc}
\hline \multirow{2}{*}{ Harga diri } & \multicolumn{3}{c}{ Resiliensi } & OR & \multirow{2}{*}{ P Value } \\
\cline { 2 - 4 } & Tinggi & Sedang & Rendah & 95\% & \\
\hline Tinggi & 34 & 20 & 11 & & \\
\hline Rendah & 14 & 19 & 32 & 367 & 0,044 \\
\hline
\end{tabular}

Berdasarkan hasil penelitian, diketahui pengguna napza dengan harga diri yang rendah paling banyak memiliki resiliensi yang rendah (49,2\%). Hasil uji statistik memperlihatkan nilai $p$-value $=0,044(\mathrm{p}<0,05)$ yang berarti bahwa ada hubungan bermakna antara harga diri dengan resiliensi pengguna napza.

\section{PEMBAHASAN}

Ada beberapa hal yang mempengaruhi pemakaian napza, satu diantaranya adalah coba-coba. Penggunaan napza lebih dari satu jenis lebih dikarenakan rasa ingin tau pengguna terhadap efek yang ditimbulkan ketika menggunakan narkotika dan psikotropika. Kebanyakan pengguna merasa efek yang diinginkan bisa didapat setelah menggunakan napza jenis gabungan tersebut. Hasil penelitian ini didukung oleh penelitian terdahulu yang telah dilakukan oleh Mustira, D (2017) dimana jenis napza yang paling banyak digunakan adalah narkotika dan psikotropika, alasan pengguna mengkobinasikan jenis napza tersebut adalah supaya cepat memperoleh efek yang diinginkan. Perlu diketahui bahwa penggunaan napza jenis ini dapat mempercepat kerusakan sistem saraf, terlebih jika penggunaan sudah berlangsung lama dan cara penggunaan adalah melalui suntikan.

Bila narkoba digunakan secara terus menerus atau melebihi takaran yang telah ditentukan akan mengakibatkan ketergantungan. Kecanduan inilah yang akan mengakibatkan gangguan fisik dan psikologis, karena terjadinya kerusakan pada sistem syaraf pusat (SSP) dan organ-organ tubuh seperti jantung, paru-paru, hati dan ginjal. Dampak penyalahgunaan narkoba pada seseorang sangat tergantung pada jenis narkoba yang dipakai, kepribadian pemakai dan situasi atau kondisi pemakai. Secara umum, dampak kecanduan narkoba dapat terlihat pada fisik, psikis maupun sosial seseorang.

Hasil penelitian ini didukung oleh penelitian terdahulu yang telah dilakukan oleh Mustira, D (2017) dimana individu dengan kategori penggunaan napza yang telah lama lebih banyak ditemukan saat ini, tidak sedikit pula individu yang telah mencoba mengikuti program rehabilitasi gagal sehingga kembali menggunakan napza.

Penggunaan napza ketika dihadapkan pada masalah bukanlah solusi yang bijak dan sangat tidak sehat. Pengguna tidak menyadari bahwa efek samping akibat penggunaan napza sangat berbahaya bagi kesehatannya. Guna membantu pengguna napza dalam meyiapkan diri untuk bisa beradaptasi dan menyelesaikan masalahnya secara sehat adalah dengan meningkatkan support sistem mulai dari lingkungan keluarga, pekerjaan, teman pergaulan, maupun tempat tinggal. Bagaimana support sistem tersebut dapat menjalankan perannya dalam memfasilitasi penggunaan koping mekanisme pengguna napza secara efektif akan sangat membantu dalam menyelesaikan persoalan penyalahgunaan napza. 
Individu yang mempunyai harga diri rendah biasanya kurang percaya diri, kurang populer, takut, menarik diri, lebih suka menjadi pendengar, kurang berani mengemukakan ide, depresi, pesimis, mudah cemas jika berhadapan dengan peristiwa sehari-hari, kurang dapat memberi dan menerima cinta, kurang intim menjalin hubungan karena takut ditolak, isolasi, malu. Kebanykan individu dengan harga diri rendah untuk mengatasi masalhanya tersebut menggunakan napza. Setelah mengkonsumsi napza mereka merasa bahwa masalahnya telah hilang dan merasa lebih percaya diri.

Resiliensi merupakan kemampuan individu untuk bangkit kembali dari tekanan hidup, belajar dan mencari elemen positif dari lingkungannya untuk membantu kesuksesan proses beradaptasi dengan segala keadaan dan mengembangkan seluruh kemampuannya, walau berada dalam kondisi hidup tertekan, baik secara eksternal atau internal.

Menurut Reivich \& Shatte (2002) dalam Dewanti \& Suprapti (2014), ada tujuh kemampuan yang membentuk resiliensi yaitu: Regulasi Emosi yang merupakan kemampuan untuk tetap tenang dalam kondisi yang penuh tekanan. Individu yang resilien menggunakan serangkaian keterampilan yang telah dikembangkan untuk membantu mengontrol emosi, atensi, dan perilakunya. Kemampuan regulasi penting untuk menjalin hubungan interpersonal, kesuksesan kerja dan mempertahankan kesehatan fisik. Tidak setiap emosi harus diperbaiki atau dikontrol ekspresi emosi secara tepatlah yang menjadi bagian dari resiliensi. Kontrol Impuls (Impulse Control) yang berkaitan erat dengan kemampuan regulasi emosi,. Individu dengan kontrol impuls yang kuat, cenderung memiliki regulasi emosi yang tinggi, sedangkan individu dengan kontrol emosi yang rendah cenderung menerima keyakinan secara impulsif, yaitu suatu situasi sebagai kebenaran dan bertindak atas dasar hal tersebut. Kondsi ini seringkali menimbulkan konsekuensi negatif yang dapat menghambat resiliensi.

Optimisme (Optimism); Individu yang resilien adalah individu yang optimis. Mereka yakin bahwa berbagai hal dapat berubah menjadi lebih baik. Mereka memiliki harapan terhadap masa depan dan percaya bahwa mereka dapat mengontrol arah kehidupannya. Dibandingkan orang yang pesimis, individu yang optimis lebih sehat secara fisik, cenderung tidak mengalami depresi, berprestasi lebih baik disekolah, lebih produktif dalam bekerja dan lebih berprestasi dalam olahraga. Analisis Kausal (Causal Analysis) merupakan istilah yang digunakan untuk merujuk pada kemampuan individu untuk secara akurat mengidentifikasi penyebab-penyebab dari permasalahan mereka. Jika seseorang tidak mampu memperkirakan penyebab dari permasalahannya secara akurat, maka individu tersebut akan membuat kesalahan yang sama.

Empati (Empathy) menggambarkan sebaik apa seseorang dapat membaca petunjuk dari orang lain berkaitan dengan kondisi psikologis dan emosional orang tersebut. Beberapa individu dapat menginterprestasikan perilaku nonverbal orang lain, seperti ekspresi wajah, nada suara dan bahasa tubuh serta menentukan apa yang dipikirkan dan dirisaukan orang tersebut. Ketidakmampuan dalam hal ini akan berdampak pada kesuksesan dan menunjukan perilaku nonresilien. Self-Efficacy menggambarkan keyakinan seseorang bahwa ia dapat memecahkan masalah yang dialaminya dan keyakinan seseorang terhadap kemampuan untuk mencapai kesuksesan. Dalam lingkungan kerja, seseorang yang memiliki keyakinan terhadap dirinya untuk memecahkan masalah muncul sebagai pemimpin. Reaching Out menggambarkan kemampuan seseorang untuk mencapai keberhasilan. Resiliensi merupakan sumber untuk mecapai reaching out. Hasil penelitian ini menunjukkan bahwa sebagian besar pengguna narkoba memiliki perilaku sosial kurang baik dikarenakan responden kurang melakukan interaksi sosial dengan lingkungan karena mereka merasa di anggap beban atau pembuat masalah di lingkungan. 


\section{KESIMPULAN}

Dari penelitian ini dapat diungkapkan bahwa ada hubungan yang bermakna antara jenis napza, lama pemakaian, harga diri, terhadap resiliasi para pengguna napza yang sebagian besar adalah pemakai lama yang menggunakan kombinasi narkotika dan psikotropika. Penelitian ini membuktikan bahwa proses resiliensi pada mantan pecandu napza ini merupakan hal yang dipengaruhi oleh faktor dukungan keluarga dan lingkungan. Terbukti dari banyaknya para pecandu yang kembali menggunakan napza setelah keluar dari rehabilitasi. Keluarga dan juga lingkungan haruslah dapat memotivasi dan mencegak kembalinya napza kepada para pecandu tersebut dengan aktif dalam memberikan pengawasan dan juga memberi bantuan yang positif agar tidak kembali terjerumus dalam napza.

\section{REFERENSI}

Coopersmith, S. (1967). The antecedents of self-esteem. San Francisco : Freeman and Company

Connor, K. M., \& Davidson, M.D. (2003). Development of a new resilience scale: The ConnorDavidson Resilience Scale (CD-RISC). Depression and Anxiety. 18, 76-82.

Dalami, E. (2009). Asuhan Keperawatan Klien dengan Gangguan Jiwa. Jakarta: TIM

Dewanti, Suprapti. (2014). Resiliensi Remaja Putri terhadap Problematika Pasca Orang Tua Bercerai. Volume 3, No. 3. Fakultas Psikologi Universitas Airlangga Surabaya

Hidayati, (2014). Hubungan Antara Self-Esteem dengan Resiliensi pada Remaja di Panti Asuhan Keluarga yatim Muhammadiyah Surakarta. Fakultas Psikologi Universitas Muhammadiyah Surakarta. Skripsi

Mustirah, D (2017). Resiliensi pada mantan pecandu napza di kampung narkoba- Madura. Skripsi. UIN Maulana Malik Ibrahim. Tidak dipublikasikan

Satria, Budi. Sazira. (2016). Resiliensi Pasien Napza Selama Masa Rehabilitasi. Vol 7 No.2. Banda Aceh. Bagian Keilmuan Keperawatan Komunitas, Fakultas Keperawatan Universitas Syiah Kuala.

Setyowati, dkk. (2010). Hubungan Antara Kecerdasan Emosional dengan Resiliensi pada Siswa Penghuni Rumah Damai. Vol 7. No. 1. Fakultas Psikologi Universitas Diponegoro. Semarang. 